\title{
Persistent Seroma, a Threat to Implant-Based Breast Reconstruction?
}

\author{
Mihaela Alexandra Radu ${ }^{1,2^{*}}$, Alexandru Blidaru ${ }^{1,2}$ \\ 'University of Medicine and Pharmacy "Carol Davila", Bucharest, Romania \\ 2Department of Surgical Oncology, "Prof. Dr. Al. Trestioreanu" Institute of Oncology, Bucharest, Romania
}

*Corresponding author: Mihaela Alexandra Radu, MD Department of Surgical Oncology, "Prof. Dr. Al. Trestioreanu" Institute of Oncology, Bucharest, Romania E-mail:drr.mihaela@gmail.com

\section{Rezumat}

Seromul persistent, o amenințare în reconstrucția mamară cu implant?

Introducere:Seromul reprezintă una dintre complicațiile postoperatorii obişnuite în chirurgia mamară şi axilară. Este considerat o consecință a limforeei prelungite. Persistența lui face ca procesul de vindecare să fie îndelungat, să existe un risc mai mare de infecție, iar în cazul reconstructiei mamare cu implant poate duce la pierderea implantului şi întârzierea tratamentului oncologic adjuvant. Mai mult decât atât, discomfortul pacientei este accentuat de vizitele frecvente la spital în vederea drenajului percutanat şi uneori poate afecta si rezultatul estetic.

Material şi metodă: Au fost incluse în studiu 137 de paciente diagnosticate cu neoplasm mamar, operate între 1999 şi 2017, în cazul cărora s-a efectuat mastectomie şi reconstrucție mamară cu implant. $\mathrm{Au}$ fost analizați factorii de risc responsabili pentru apariția seromului şi s-a implementat un algoritm de urmărire ecografică postoperator şi de evacuare a seromului prin puncție aspirativă sub ghidaj ecografic.

Rezultate: Seromul a fost identificat în $9.49 \%$ din cazuri (13/137 paciente). Ischemia lambourilor cutanate a fost asociată în $37.5 \%$. Factorii de risc pentru apariția seromului au fost: utilizarea plaselor sintetice, fumatul şi greutatea corporală mare. Au fost pierdute 3 implanturi din cauza seromului, reprezentând 2,18\%. In cazul pacientelor cu limforee prelungită, pe lângă puncția aspirativă sub ghidaj ecografic s-a efectuat şi lavajul periprotetic cu soluție de Rifampicină. După lavaj, drenajul s-a redus cu 50\% după fiecare vizită.

Conclusion: Pacientele cu greutate corporală mare şi fumătoarele prezintă un risc mai mare de aparitiie a seromului după reconstrucția mamară cu implant. Utilizarea plaselor sintetice este de 
asemenea un factor de risc pentru serom. Lavajul cu soluție de Rifampicină ar putea fi o opțiune pentru a reduce limforeea.

Cuvinte cheie: reconstrucție mamară, implanturi, serom, puncție aspirativă sub ghidaj ecografic, instilații cu Rifampicină.

\begin{abstract}
Introduction: Seroma is one of the usual postoperative complications after breast and axillary surgery. It is considered as a consequence of prolonged lymphorrhea. Its persistence means a longer healing process, increased risk of infection and in case of implant-based reconstruction, even implant loss which may result in delaying adjuvant oncologic treatment. Nevertheless the patient's discomfort is amplified due to frequent follow-up visits to the hospital for percutaneous drainage and sometimes the seroma might affect the aesthetic result.

Materials and methods: Between 1999 and 2017 a total of 137 patients with mastectomy and implant-based breast reconstruction were included in the study. The risk factors for developing seroma were analyzed and an algorithm for postoperative follow-up and ultrasound-guided needle aspiration was implemented.

Results: The seroma rate was $9.49 \%$ (13/137 patients). It was associated with skin flap ischemia in $37.5 \%$. Risk factors for developing seroma were: the use of synthetic mesh, smoking and overweight. The rate of implant loss attributed to seroma was $2.18 \%$ (3/137). In patients having prolonged lymphorheea, beyond ultrasound-guided needle aspiration, Rifampin solution was used to wash the implant pocket. In these cases, the drainage was reduced by $50 \%$ after each visit.

Conclusion: Overweight patients and smokers have a higher risk of developing seroma after implant- based breast reconstruction. The use of synthetic meshes for breast reconstruction is also a risk factor for seroma. Rifampin solution for washing the implant pocket might be an option for decreasing the lymphorrhea.
\end{abstract}

Key words: breast reconstruction, implants, seroma, ultrasound-guided aspiration, Rifampin instillation

\section{Introduction}

Seroma naturally appears after breast and axillary surgery and it is defined by fluid accumulation in the axilla, peri-implant, or between the muscular plane and the subcutaneous layer. The breast might look swollen, or if the quantity of liquid is not significant, might appear normal.

There are early postoperative seromas and late seromas. Early postoperative seromas tend to appear immediately after the drainage tubes have been removed or within one year. Late seromas develop after more than one year from the surgery (1). The cause is largely unknown. Interruption of the lymphatic flow, surgical dissection and shear forces between tissue layers are involved.

In case of late seroma and BIA-ALCL (breast-implant associated anaplastic large cell lymphoma) the timing until appearance is more than one year after implantation (in average 7-9 years). Special immunohistochemistry and MRI have to be performed in order to exclude this implant-related late complication. Tumor cells are CD30 positive and ALK negative. A multidisciplinary team is needed to establish the treatment in these cases (2).

Different methods were tried to reduce 
lymphorrhea after surgery: stitches between the muscular and cutaneous planes, fibrineglue, octreotid and compressive garments, without any significant results. The only effective management remains percutaneous aspiration (3).

\section{Materials and Methods}

Between 1999 and 2017 a total of 137 patients were included in the study. They were diagnosed with breast cancer and the operation was performed by the same surgical team. The surgical intervention was mastectomy and implant-based breast reconstruction. The reconstruction was performed either direct-toimplant or as a two-stage procedure (expander limplant). The implants were placed using 3 surgical techniques: completely submuscular, or partially submuscular and covered in the lower pole with synthetic mesh (Seragyn $\mathrm{BR}^{\circledR}$ ) or prepectoral with or without synthetic mesh.

The study has two parts: a retrospective part, with 56 patients, starting from 1999 to 2014 and a prospective part with 81 patients from 2014 to 2017 . The mean follow-up was 93 months. The median age of the patients was 43 years old with a coefficient of variation of $17 \%$ and the median BMI was 22.65 with a standard deviation of 3.03 .

The risk factors for developing seroma were analyzed and an algorithm for postoperative follow-up and ultrasound-guided needle aspiration was implemented.

After implant-based breast reconstruction all patients have aspirative drainage systems (Fig. 1). Considering the type of reconstruction and the implant placement the drains are above and/or beneath the muscular plane and sometimes in the axilla, if needed. The drains are maintained for 7-14 days. Usually after having for more than two consecutive days less than $50 \mathrm{ml}$, the drains are removed. Even if there is high volume persistent drainage, the drainage tubes are not kept for more than 2-3 weeks, because of the risk of infection.

The first ultrasound evaluation is made 2-4 days after the drains are removed. If there is any liquid accumulation, it is evacuated after

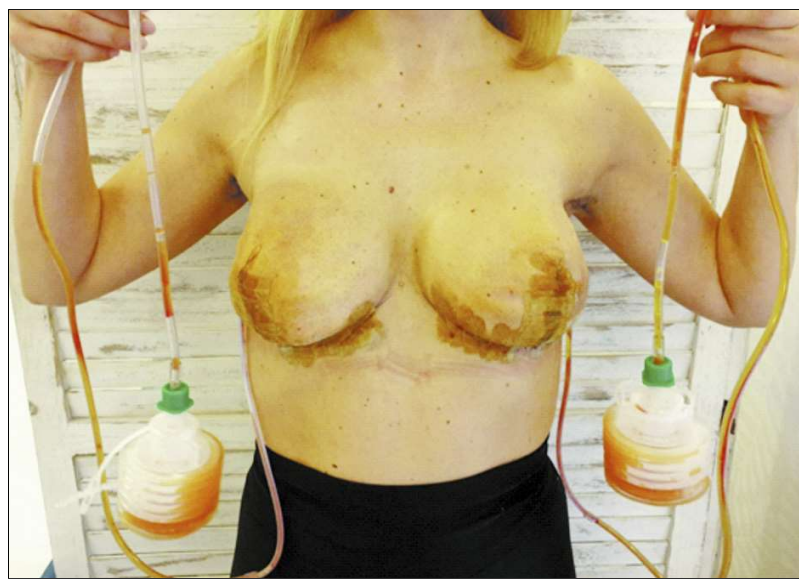

Figure 1. Bilateral skin-reducing mastectomy with immediate implant-based breast reconstruction. One week postoperative.

ultrasound-guided puncture, using $18 \mathrm{G}$ or 21 $\mathrm{G}$ needles, respecting the rules of asepsis and antisepsis (Figs. 2, 3). The needles are chosen after evaluating the consistency of the liquid. (Fig. 4). In certain cases, if the amount of liquid after the drain removal is estimated to be less than $10 \mathrm{ml}$, no postoperative aspiration is needed. Considering the extracted volume, we have applied the postoperative ultrasound follow-up (Fig. 5).

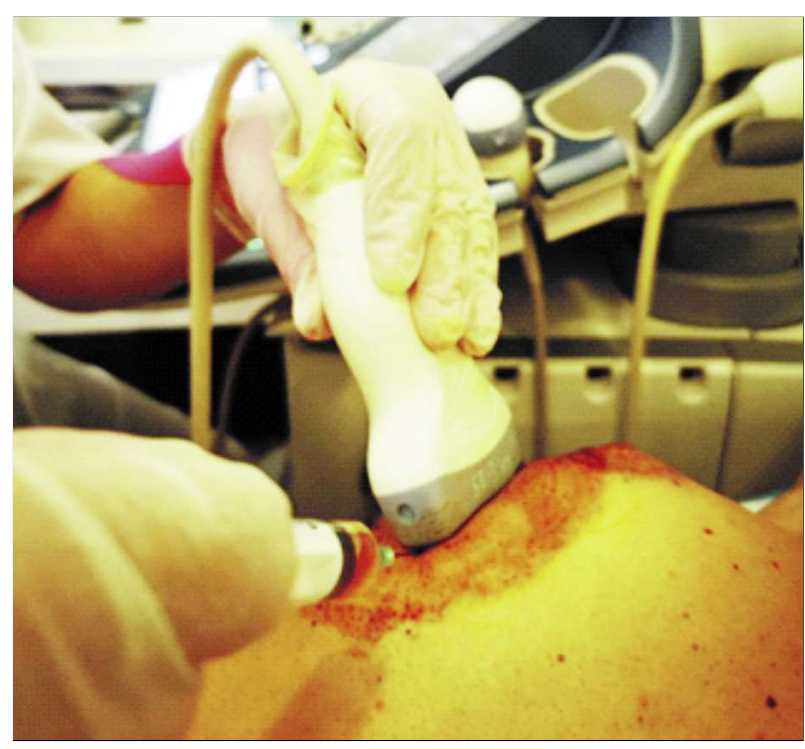

Figure 2. Nipple-sparing mastectomy with immediate implant based-breast reconstruction. First ultrasound-guided aspirative puncture, after removing the drainage tubes. $21 \mathrm{G}$ needle because of the soft consistency of the fluid 


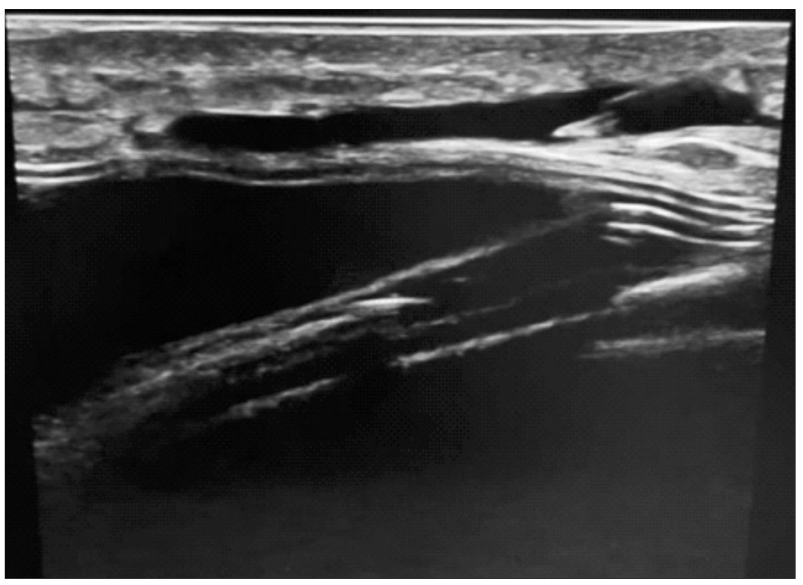

Figure 3. Expander breast reconstruction - ultrasound aspect of the aspirative needle puncture

Persistent seroma was considered in case of more than $100 \mathrm{ml}$ drainage per week, after 4 weeks postoperative.

If there was persistent lymphorrhea 3 weeks after drainage removal, bacteriological examination was performed. If the cultures were positive then antibiotic treatment was initiated according to the antibiogram. The antibiotics were administered per os or intravenously and also a drainage tube was repositioned after ultrasound guidance, for washing the implant pocket using antibiotic solution.

In case of negative cultures and persistent

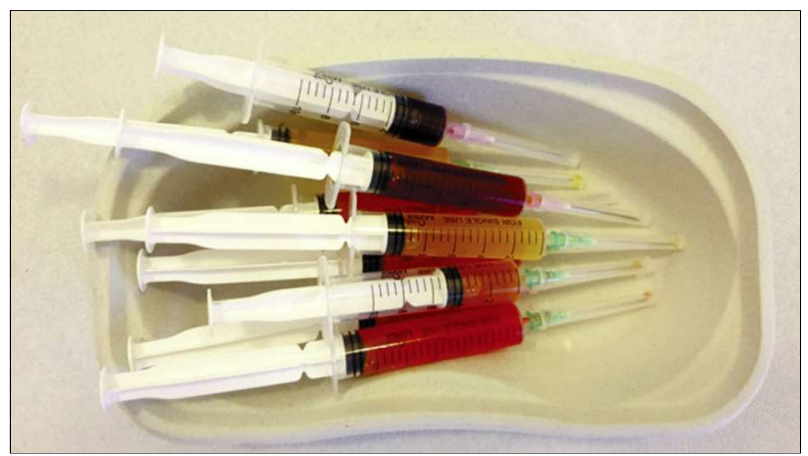

Figure 4. Different seroma consistencies

lymphorrhea, Rifampin solution was used to wash the implant pocket, under ultrasound guidance. The Rifampin solution is prepared with $300 \mathrm{mg}$ Rifampin in $500 \mathrm{ml}$ saline solution. The patients are tested before, for Rifampin allergy.

If the seroma was associated with wound dehiscence, the wound dehiscence was sutured using separate non-resorbable monofilament stitches and one drain was placed around the implant under ultrasound guidance.

The statistical analysis was made with SPSS Statistics 23, using the following statistic tests: Chi square, Fisher's exact test, Wilcoxon-Mann-Whitney, Kursakal Wallis, Phi and Cramer's.
Figure 5. Postoperative ultrasound follow-up algorithm

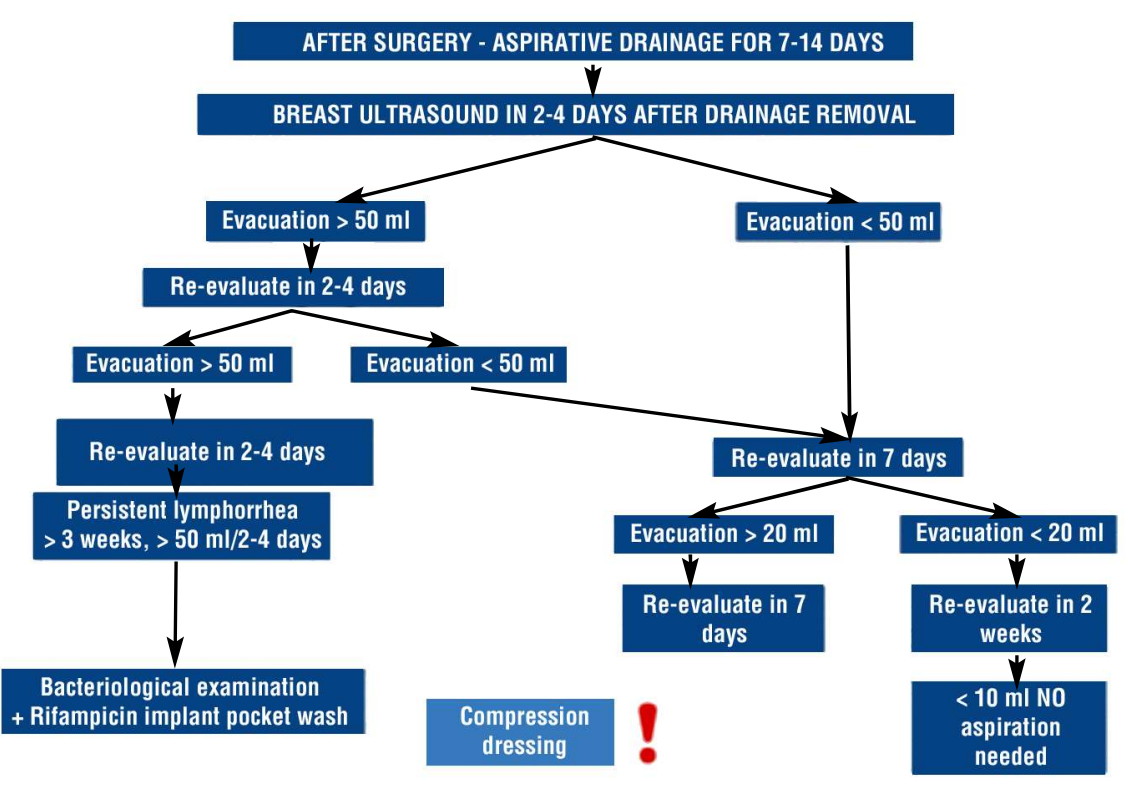




\section{Results}

The rate of seroma was $9.49 \%$ (13/137 patients) and 3 implants were lost because of seroma and wound dehiscence (2.18\%). Seroma associated with skin flap ischemia was found in $37.5 \%$ of the cases.

Risk factors for developing seroma were: the use of synthetic mesh, smoking and overweight.

Smoking is an important risk factor. Smokers had a risk of $25 \%$ of developing seroma, compared to non-smokers, where the risk was $7 \%$. The risk of seroma in smokers is 5.6 times higher

The risk of developing seroma, if synthetic mesh was used for the breast reconstruction, was $18 \%$. For the patients without meshes the risk was only $5 \%$, so there is a 4.7 higher risk of developing seroma in patients with synthetic meshes.

There was a correlation between the weight of the patients and seroma - especially in patients having over $80 \mathrm{~kg}$.

The link between these three risk factors and seroma is a direct one. $\mathrm{B}$ regression $\mathrm{co}^{-}$ efficients have positive values, being significant with a significance level of $5 \%$ and the „weight" factor of $10 \%$ (Table 1).

Bacteriological examination was performed in 6 patients $(46 \%)$, with positive results in 3 cases (23\%) - one infection with Escherichia coli (E.coli) and two with Staphylococcus aureus (S. aureus). Systemic antibiotic therapy was iniatiated, for 7 days, according to the antibiogram (Cefuroxime for S. aureus and Ciprofloxacin for E.coli), ultrasoundguided reinsertion of the drainage tubes and instillations with antibiotic solution was performed daily. In patients with seroma, infection and wound dehiscence, 2 implants were saved after placing the drains again, antibiotic implant pocket wash and suturing the dehiscent part.

Three implants were lost: one patient with seroma and infection and two patients with seroma, wound dehiscence and negative bacteriological examination.

For patients with prolonged lymphorrhea, after two Rifampin implant pocket wash made 3-5 days apart, the amount of the extracted liquid was $50 \%$ lower after each visit.

The longest time of postoperative lymphorrhea, with repeated negative bacteriological cultures was 4 months long and was observed in one patient with neoadjuvant chemo-therapy, bilateral nipple-sparing mastectomy with immediate breast reconstruction and prepectoral implants. After several aspirative punctures and eventually Rifampin pocket wash, the lymphorrhea stopped.

Persistent seroma was observed mainly peri-implant. Axillary seroma was rarely seen.

No adjuvant treatment was delayed because of seroma in this group.

There were no patients diagnosed with late seroma and BIA-ALCL in this study.

Table 1. Statistic link between the risk factors and seroma formation

\begin{tabular}{|c|c|c|c|}
\hline \multicolumn{4}{|c|}{ Model Summary } \\
\hline Step & -2 Log likelihood & $\begin{array}{l}\text { Cox \& Snell } \\
\text { R Square }\end{array}$ & $\begin{array}{c}\text { Nagelkerke } \\
\text { R Square }\end{array}$ \\
\hline 1 & $70.780^{\mathrm{a}}$ & 0.105 & 0.225 \\
\hline
\end{tabular}

\begin{tabular}{|c|c|c|c|c|c|c|c|c|c|}
\hline \multicolumn{10}{|c|}{ Variables in the Equation } \\
\hline & & \multirow[t]{2}{*}{ B } & \multirow[t]{2}{*}{ S.E. } & \multirow[t]{2}{*}{ Wald } & \multirow[t]{2}{*}{ df } & \multirow[t]{2}{*}{ Sig. } & \multirow[t]{2}{*}{$\begin{array}{c}\operatorname{Exp}(B) \\
O R\end{array}$} & \multicolumn{2}{|c|}{ 95\% C.I.for EXP(B) } \\
\hline & & & & & & & & Lower & Upper \\
\hline \multirow[t]{4}{*}{ Step $1^{\text {a }}$} & Weight & 0.067 & 0.036 & 3.440 & 1 & 0.064 & 1.069 & 0.996 & 1.147 \\
\hline & Synthetic mesh & 1.547 & 0.655 & 5.576 & 1 & 0.018 & 4.698 & 1.301 & 16.966 \\
\hline & Smoking & 1.726 & 0.700 & 6.073 & 1 & 0.014 & 5.618 & 1.424 & 22.167 \\
\hline & Constant & -7.661 & 2.466 & 9.654 & 1 & 0.002 & 0.000 & & \\
\hline
\end{tabular}




\section{Discussion}

A comprehensive review of seroma after axillary dissection in breast cancer showed that the incidence of seroma varies from $1.8 \%$ to $88.3 \%$ (4). Regarding implant-based reconstruction, the seroma rate is reported up to $20 \%$, compared to $9.49 \%$ in this paper (5). Seroma management in our study required ultrasound-guided aspirative needle puncture. The liquid evacuation might be done using SeromaCath, Veress needle or by operative drainage, if necessary (6-8). In 3 cases, the drainage tubes were repositioned without re-entering the operating room, after local anesthesia and ultrasound guidance.

Axillary seroma was rare because most of the patients included in the study had only sentinel lymph node biopsy. Nevertheless, quilting sutures were performed and this might be the reason for not having frequent axillary seroma. Axillary drainage tubes were not necessary in all patients. Quilting flaps and closure of the axillary space lowered significantly the duration and volume of the lymphorrhea $(9,10)$.

Seroma also seems to be linked to the surgical procedure: the extent and duration of the procedure have an influence on seroma formation (11). Other factors like the use of blunt dissection, or sharp scissors or harmonic scissors for the mastectomy skin flaps have demonstrated no significant difference (12). Thunderbeat, which uses hybrid energy, ultrasonic and advanced bipolar, seems to have a lower seroma incidence (13). In our study dissection was performed using monopolar electrocautery and scissors.

Fibrin glue was used to seal the axilla after lymphadenectomy, but there was no significant improvement in drainage volume and time, or seroma formation (14).

It was thought that arm movements will increase the amount of liquid accumulation. The limitation of the arm movements showed no improvement in seroma formation, but led to the disability of the shoulder. Routinely arm movement is encouraged after the surgery (4).

If seroma appears, the patient will have twice a higher risk of developing lymphedema. (15). Probably seroma and lymphedema have the same mechanism of appearance, without meaning that seroma causes long-term lymphedema.

Factors influencing seroma formation and the number of days before the drain removal are debatable (16). Seems that seroma formation and the number of days before the aspiration drains are removed, are not influenced by the initial inflation of the expander and ADM (acellular dermal matrix) use, still in elderly patients and patients with bigger volume expanders, the postoperative drains remain for a longer period of time (17). Our study did not consider the expander volume. For us, the implant loss rate because of seroma, without ADM is $2.18 \%$, while other authors report $12 \%$, after using $\mathrm{ADM}$ (18). A comparison between the use of ADM and synthetic meshes started in 2019 and will be published by our team.

Factors like hypovascular mastectomy skin flap, the presence of a foreign body with biofilm and the dead space after the surgery associated to seroma are responsible for the evolution towards infection and implants loss. (19). The results of our study sustain that there is a connection between seroma and skin flap ischemia. Thinking about the biofilm and trying to prevent the risk of infection the Rifampin solution was introduced. The Rifampin solution was used after the good orthopedic experience for implant infection, without removal of the implants (20). In a rat model the Rifampin was used as an agent for preventing capsule formation around the silicone implants and proved its bactericidal effect against Stapylococcus epidermidis (21). The Rifampin solution had good results for reducing lymphorrhea in this study, but because of the limited number of patients who benefited from this method, further studies will be performed.

Risk factors for seroma formation in aesthetic breast surgery, after breast augmentation are: large implant size, high BMI, smoking and submammary pocket (1). Smoking and overweight were found to be 
important risk factors for seroma in this study. Implant size was not associated with seroma, but probably the implant texture is also important. The majority of the implants used in our study were textured. The mean follow-up was 93 months and no case of BIA-ALCL and late seroma was noticed.

Immediate reconstruction after mastectomy without complications is not delaying the adjuvant oncologic treatment. If complications are present the treatment could be delayed with a median of 6 days (22). Most patients in this study received neoadjuvant chemotherapy, so this could be an important factor for not having a delay in receiving adjuvant chemotherapy. None of the patients with persistent seroma had indication for adjuvant radiotherapy.

\section{Conclusions}

Seroma is an usual complication after breast and axillary surgery. Different methods were attempted to reduce seroma formation, like quilting sutures or compressive garments with limited results. However, there are risk factors for developing seroma and this study confirmed three of them: overweight patients, smokers and the use of synthetic meshes. For implant-based breast reconstruction persistent seroma might be a threat because of the risk of infection, wound dehiscence and implant loss

Adequate postoperative follow-up and evacuation of the seroma, lowers the risk of implant loss. An algorithm for ultrasound follow-up was implemented in order to have an accurate evaluation and to establish the frequency of the hospital visits.

In case of infection, besides oral or intravenous antibiotic therapy, repositioning the drainage tubes and washing the implant pocket with antibiotic solution, may save the implant from explantation. In case of prolonged lymphorrhea, with negative cultures, washing the implant pocket with Rifampin solution is an option for reducing the duration and volume of seroma.

\section{Conflicts of Interest and Source of Funding}

The authors declare no conflicts of interests and no financial disclosure.

\section{Ethics Approval}

Ethics Committee Approval was not needed. Internal protocols for private practice were applied.

\section{References}

1. Sforza M, Husein R, Atkinson C, Zaccheddu R. Unraveling Factors Influencing Early Seroma Formation in Breast Augmentation Surgery. Aesthet Surg J. 2017:37(3):301-307.

2. Breast implant-associated ALCL. guidelines, NCCN. 2020.

3. Srivastava V, Basu S, Shukla VK. Seroma formation after breast cancer surgery: what we have learned in the last two decades. J Breast Cancer. 2012:15(4):373-80

4. van Bemmel A J M, van de Velde C J H, Schmitz R F, Liefers G J. Prevention of seroma formation after axillary dissection in breast cancer: a systematic review. Eur J Surg Oncol. 2011;37(10):829-35.

5. Lam TC, Hsieh F, Salinas J, Boyages J. Immediate and Long-term Complications of Direct-to-implant Breast Reconstruction after Nipple- or Skin-sparing Mastectomy. Plast Reconstr Surg Glob Open. 2018;6(11):e1977.

6. Becker H, Klimczak J. Aspiration of Periprosthetic Seromas Using the Blunt SeromaCath. Plast Reconstr Surg. 2016;137(2):473-475.

7. Brzezienski MA, Jarrell $4^{\text {th }} \mathrm{JA}$, Mooty RC. Classification and management of seromas in immediate breast reconstruction using the tissue expander and acellular dermal matrix technique. Ann Plast Surg. 2013;70(5):488-92.

8. Mazzocchi M, Dessy LA, Marchetti F, Marchetti F, Carlesimo B. The use of the Veress needle to drain mammary periprosthetic fluid. In Vivo. 2010; 24(2):219-22.

9. Khater A, Elnahas W, Roshdy S, Farouk O, Senbel A, Fathi A, et al. Evaluation of the Quilting Technique for Reduction of Postmastectomy Seroma: A Randomized Controlled Study. Int J Breast Cancer. 2015; 2015:287398.

10. Arafa AS, Fayek F, Awad JR. Efficacy of mastectomy flap fixation in minimizing seroma formation after breast cancer surgery. Egypt J Surg. 2019;38(4):656-61.

11. Ebner F, Friedl TW P, de Gregorio A, Lato K, Bekes I, Janni W, et al. Seroma in breast surgery: all the surgeons fault? Arch Gynecol Obstet. 2018;298(5): 951-959.

12. Karimian F, Kondori H, Mosavizadeh SM, Neishaboury M, Abbaszadehkasbi A, Keramati M. Seroma Formation After Mastectomy and Axillary Dissection; A Comparison Among Blunt Dissection With Hemostat, Sharp Dissection With Metzenbaum Scissors, and Dissection With Harmonic Scissors. Breast Cancer 2018;5(1):38-43.

13. Gambardella C, Clarizia G, Patrone R, Offi C, Mauriello C, Romano R, et al. Advanced hemostasis in axillary lymph node dissection for locally advanced breast cancer: new technology devices compared in the prevention of seroma formation. BMC Surg. 2019;18(Suppl 1):125.

14. Berger A, Tempfer C, Hartmann B, Kornprat P, Rossmann A, Neuwirth G, et al. Sealing of postoperative axillary leakage after axillary lymphadenectomy using a fibrin glue coated collagen patch: a prospective randomised study. Breast Cancer Res Treat. 2001;67(1):9-14.

15. Toyserkani NM, Jørgensen MG, Haugaard K, Sørensen JA. Seroma indicates increased risk of lymphedema following breast cancer treatment: A retrospective cohort study. Breast. 2017;32:102-104.

16. Chen CF, Lin SF, Hung CF, Chou P. Risk of infection is associated more with drain duration than daily drainage volume in prosthesis-based breast 
reconstruction: A cohort study. Medicine (Baltimore). 2016;95(49):e5605.

17. Woo KJ, Myong Paik J, Mun GH, Pyon JK, Jeon BJ, Bang Sl. Analysis of factors influencing drain amount, time to drain removal, and seroma formation in patients undergoing immediate expander-implant breast reconstruction. J Plast Surg Hand Surg. 2018; 52(1):53-59.

18. Berna G, Cawthorn SJ, Papaccio G, Balestrieri N. Evaluation of a novel breast reconstruction technique using the Braxon $₫$ acellular dermal matrix: a new muscle-sparing breast reconstruction. ANZ J Surg. 2017;87(6):493-498.

19. Jordan SW, Khavanin N, Kim JY S. Seroma in Prosthetic Breast Reconstruction. Plast Reconstr Surg. 2016;137(4):1104-1116.
20. Zimmerli W, Widmer A F, Blatter M, Frei R, Ochsner P E. Role of rifampin for treatment of orthopedic implant-related staphylococcal infections: a randomized controlled trial. Foreign-Body Infection (FBI) Study Group. JAMA. 1998;279(19):1537-41.

21. Unlu RE, Yilmaz AD, Orbay H, Can B, Tekdemir I, Sensoz 0. Influence of rifampin on capsule formation around silicone implants in a rat model. Aesthetic Plast Surg. 2007;31(4):358-64.

22. Eck DL, McLaughlin SA, Terkonda SP, Rawal B, Perdikis G. Effects of immediate reconstruction on adjuvant chemotherapy in breast cancer patients. Ann Plast Surg. 2015;74 Suppl 4:S201-3. 